\title{
8 Revenge and Forgiveness
}

My foster father [Lichter] was the one who pushed this thing forward..$^{300}$

In the morning they went to see an execution. I don’t know what their afternoon was like. ${ }^{301}$

\subsection{The frameworks of justice}

Post-Second World War justice represented the institutionalized remembrance of the past. W. James Booth differentiated three methods of "justice as it deals with the past: trial and punishment (criminal charges); illumination and acknowledgement (truth commissions); and forgetting for a sake of a future in common (amnesty)." ${ }^{302}$ All three were present in the Hungarian case; at the same time most denouncements were fueled by revenge. ${ }^{303}$ There is a general silence from survivors about feelings of satisfaction and happiness experienced when witnessing trials and executions are strictly tabooed topics. The post-Second World War trials were expected to negotiate and harmonize emotions to form "emotional communities" ${ }^{304}$ besides marking out what is good, bad or acceptable. The court was a highly ritualized space where the audience was expected to be silent, therefore we can access the emotions constructed during the trials only through the testimonies. Emotions usually escape the attention of historians, as they do not leave any written trace behind. The VHA video testimony collection is unique as it explicitly asks questions about feelings. ${ }^{305}$

300 Interview with Magda Kun, March 3, 2005.

301 Interview, April 1, 2005. Until March 1946 women could not watch the executions, but then this discriminative measure was found unconstitutional. (MOL XIX-E-1-L X. 2. box Bö 1466/1945. 5.)

302 W. James Booth, “The Unforgotten. Memories of Justice,” The American Political Science Review 4 (2001): 777-791, 778.

303 Andrea Peto", "Digitalized Memories of the Holocaust in Hungary in the Visual History Archive," in Holocaust in Hungary 70 years after, ed., Randolph Braham and András Kovács (CEU Press, Budapest, 2016), 253-261.

304 Barbara Rosenwein, "Worrying about Emotions in History," American Historical Review 107.3 (2002): 842.

305 More on this see Andrea Peto", "Historicizing Hate: Testimonies and Photos about the Holocaust Trauma during the Hungarian post-WWII Trials," in Tapestry of Memory. Evidence and Testimony in Life Story Narratives, ed., Nanci Adler and Selma Leydesdorff (New York/London: Transaction Publishers, 2013), 3-19. 
But who could take revenge and for what? Special importance was given to the process because of the victims who could not stand up for themselves: the denouncers fought for their own dignity. However, punishment should be just.

Hungary established two institutions for the examination of wartime events, the people's tribunals following the Soviet example and the bottom up initiative of the Committee for the Investigation of Nazi and Arrow Cross Atrocities, founded on March 7, 1945 after the lead of Béla Varga. Until September 17, 1945 the Committee collected 12,000 questionnaires in which Budapest inhabitants listed house by house what happened during the Arrow Cross rule. The Committee's goals were defined as follows:

[In order to] not let the past fall into the waters of forgetfulness. [...] [T]o find out what happened for the sake of the future of Hungarian nation. The people's tribunals execute dozens of mass murderers, the political police investigates case $\mathrm{x}$, but terminates investigation in case y because the perpetrators are unknown. This is not enough. We also need to know and share with the international community the psychological reasons and the evidences, which prove that the mass murderers were criminals under other circumstances too. [...] [T]o prove that they were foreign to Hungarian people, sometimes even their names were foreign like Mesztl who took on the Hungarian name Murai [...]. ${ }^{306}$

The declared aim of the committee's work was to contribute to social science research, but in particular cases it could also provide a basis for criminal procedures. ${ }^{307}$ In the meantime, the Hungarian Communist Party (MKP - Magyar Kommunista Párt) tried to sabotage the committee's operation. For the MKP such a wide-based democratic project seemed uncontrollable. Therefore, soon enough the People's Tribunals, which were supervised by the Ministry of Justice, which in turn was controlled by the Communist Party, remained the only institutional channels of punishment.

Besides Andor Lichter there was another engine behind the Csengery 64 justice process: Pál Kádár people’s prosecutor, later people's judge. ${ }^{308}$ Although during the shooting Kádár played dead, he was put into the first transport from where he escaped with forged papers. For the purposes of the Committee for the Investigation of Nazi and Arrow Cross Atrocities, Kádár summarized what happened in the Csengery Street. In his view there were 21 "improvised" killings by "8-10 SS soldiers, 3 Arrow Cross men and an Arrow Cross woman." 309

306 BFL XVII-2.18. 13-14.

307 BFL XVII-2.19. 38. March 9, 1945.

308 BFL XVII-2.19. 164. Application for the people's prosecutor's office. (MOL XIX-E-1-L X. 1. Ta 1777/1945.)

309 BFL XVII-2.19. 164. on February 23, 1945 
Nothing proves that Lichter and Kádár collaborated, but the fact that a people's prosecutor was a witness during the Csengery 64 trials gave the case extra gravity. Pál Kádár always talked straightforwardly and genuinely by which he greatly aided the justice process. When he applied for the position of people's judge (with recommendations from Zoltán Tildy, the first, and Árpád Szakasits, the second President of Hungary after 1945), his argument was: "The Arrow Cross and the fascists partly killed partly deported my family and they deported me too. For these personal reasons my deepest commitment and desire is to chase fascists and reactionaries within the framework of legality but with all strictness of law." 310

\subsection{Moral witness or political witness?}

Whom did Andor Lichter represent? Did he have a choice? Avishai Margalit holds that someone is a moral witness if they act upon clear moral aims, ${ }^{311}$ while they take personal risk. ${ }^{312}$ Lichter took a risk indeed, and not a negligible one. That is one of the reasons, when he believed that Communist Hungary had collapsed, on 23 October, 1956 that he made sure his meticulously collected files would be burned. ${ }^{313}$

Annette Wieviorka describes the complex process through which survivors become witnesses: the process of remembrance is taken to a new space and this new space provides legitimacy to their memories. ${ }^{314}$ Could Lichter come to terms with himself had he not acted the way he did? Moral witnesses should establish a moral community of their present and future selves; but as a prerequisite they should validate a moral standpoint. The authority of a moral witness is rooted in a deep commitment that allows for no compromise: "[A] strong congruence between his emotions and his avowals, and with his not making concessions to himself." 315

310 MOL Ta 1777/1945.

311 Avishai Margalit, The Ethics of Memory (Cambridge, Mass.: Harvard University Press, 2001), 151.

312 Ibid., 157.

313 Interview, April 1, 2005.

314 Annette Wieviorka, "From Survivor to Witness. Voices from the Shoah," in War and Remembrance in the Twentieth Century, ed., Jay Winter and Emmanuel Sivan (Cambridge: Cambridge University Press, 1999).

315 Avishai Margalit, The Ethics of Memory (Cambridge, Mass.: Harvard University Press, 2001), 170. 
Margalit compares the concept of moral witness to the concept of political witness. The political witness says what happened, but the moral witness says what it was like to face the devil. ${ }^{316}$ For that Lichter did not have to be personally present in Csengery Street on October 15, 1944. "The moral witness plays a special role in uncovering the evil he or she encounters. ${ }^{317}$ Piroska Dely was "devillike" exactly because she was so ordinary.

But what about the fact that Lichter lied to those institutions, which were officially after the "truth"? ${ }^{318}$ To answer that question we should separate the truth of memory and the memory of truth:

Truth-memory is [...] an act of fidelity [...] to members of one's community who have been lost. Memory-truth is not a gesture of fidelity to just anyone it is faithfulness in the context of a community, whether a marriage, a religion, or a nation. The truth of remembrance differs from the truth of law and history in that its core is fidelity to the victim. [...] Remembrance serves to reintegrate the victims into their community and to restore that community after the rupture induced by the crime. Faithfulness and the (re)integration of the community are two sides of the same phenomenon. ${ }^{319}$

Leigh A. Payne - borrowing from Elizabeth Jelin - uses the term memory entrepreneur. ${ }^{320}$ A memory entrepreneur is a person who "turns" past events into political deeds. Andor Lichter was a memory entrepreneur as well as a memory militant: he put principles of his memory politics into practice. Lichter's memories conformed to the 'memory of truth' but not to 'the truth of memory.' The way he fought for the truth of law did not restore the community, although that was what he wished for. As he individually waged this fight against forgetting, his impact on the process was therefore provisional and lacked long term perspective.

316 Ibid., 168.

317 Ibid., 165.

318 For more, see Daniel L. Schacter, ed., Memory Distortion. How Minds, Brains and Societies Reconstruct the Past (Cambridge, Mass.: Harvard University Press, 1994).

319 W. James Booth, "The Unforgotten. Memories of Justice," The American Political Science Review 4 (2001):787.

320 Leigh A. Payne, Unsettling Accounts. Neither Truth nor Reconciliation in Confessions of State Violence (Durham, NC/London: Duke University Press, 2008), 37. 


\subsection{The affect of testimony}

What if Lichter had died on October 15, 1944 in the Újpest Hospital, if he really had dysentery? How much would we know about the Csengery Street massacre today? How would we think about invisible perpetrators? Would we consider Piroska Dely a "beast in human skin"? How would we remember the first massacre committed by the Arrow Cross? The answers are twofold: on the one hand, Lichter's denouncements should be interpreted within the matrix of forgiving and forgetting in post-war Hungary. ${ }^{321}$ Secondly, it should be analyzed whether Lichter was truly a moral witness since he was not part of the events, he did not see the massacre, but still, he testified as an eyewitness. ${ }^{322}$

Dori Laub separates three levels of witnessing. The first level is being witness to oneself in the experience, the second level is being witness to someone else's testimony, and the third level is being witness to someone else's witnessing. ${ }^{323}$ Laub considers that the third level to be missing from the Holocaust experience. ${ }^{324}$ However, in the Csengery case the opposite is true. The remembrance of the experience was created through the act of witnessing.

But we would misrepresent the events if we posited Lichter as the sole engine of them. Lichter as a lettered, respectable man certainly played a huge role during the trials but the rest of the tenants also participated in the process. Edit Rosenberg, from Csengery Street, could not imagine the belligerent and passionate statements her mother made in front of the people's tribunal until I showed her the court records. She remembered her mother as "bunnylike."325 This shows that although the People's Tribunal played a key role in the shaping of post-war memory their later experiences modified their remembrance of events. In the long run in socialist Hungary it was more beneficial to adopt a "bunny-like" attitude than to be a fierce warrior.

321 Martha Minow, Between Vengeance and Forgiveness. Facing History after Genocide and Mass Violence (Boston: Beacon Press, 1998).

322 See his detailed, descriptive testimony made on December 26, 1946. (BFL 19273/1949. 231233.) The basis of the testimony was that he questioned his wife thoroughly. In his testimony he tried to accuse Mrs. Strucky's cousin, István Kiss and his wife too because they regularly visited the Struckys and participated in the transport of stolen goods. During his testimony he exhibited exceptional preparedness concerning the structure and functioning of the Arrow Cross.

323 Dori Laub, “An Event Without a Witness. Truth, Testimony and Survival," in Testimony. Crises of Witnessing on Literature, Psychoanalysis and History, ed., Soshana Felman and Dori Laub (New York: Routledge, 1992), 75.

324 Ibid., 80.

325 Interview with Edit Rosenberg. 
Hannah Arendt in Eichmann in Jerusalem says: "One man will always be left to tell the story." 326 This is certainly true, however in the case of Csengery Street the one man who told the story was not an eyewitness. Lichter was a sharp man though. He strategically placed Mária Verebes, the Lichter family's loyal maid, at the Szamocseta's home when the Jews were not allowed to employ Christian maids anymore: "[I told her to] Please keep your eyes open and tell me everything that happens around the Struckys and the Szamocsetas, because I expected that they would pay for their crimes." 327 Verebes's information and her testimonies were indeed very useful during the court process.

"Forgiving means overcoming anger and vengefulness," 328 says Avishai Margalit. Lichter was far from that. But what could the opposite strategy be? Forgetting? "Forgetfulness may in the last analysis be the most effective method of overcoming anger and vengefulness, but since it is an omission rather than a decision, it is not forgiveness." 329 Margalit argues that it is not forgetting that should be the base of forgiveness but the ignorance of $\sin .{ }^{330}$ However, the ignorance of sin cannot be an accidental mental act, it should be an active process, which brings with it mental change. This is why it cannot be connected to forgetting, because forgetting is involuntary while forgiveness is deliberate. ${ }^{331}$ Forgiveness is a process and a result at the same time. ${ }^{332}$

For the returned Jews it was key to assuaging the damage. ${ }^{333}$ In a European comparison - as Pierre Lagrou demonstrates - Hungary did not differ from other countries where the Germans exterminated local Jewry in collaboration with representatives of local institutions. ${ }^{334}$ After the war, national organizations buried

326 Hannah Arendt, Eichmann in Jerusalem. A Report on the Banality of Evil (London/New York: Penguin Books/Viking Press, 1994). 232-233.

327 Andor Lichter's testimony, December 27, 1946. BFL 19273/1949. 229-230.

328 Avishai Margalit: The Ethics of Memory (Cambridge, Mass.: Harvard University Press, 2002). 192.

329 Ibid., 193.

330 Ibid., 197.

331 Ibid., 203.

332 Ibid., 205.

333 On the post-1945 social history of Hungarian Jewry, see Karády Viktor, Szociológiai kísérlet a magyar zsidóság 1945-1956 közötti helyzetének elemzésére, Zsidóság az 1945 utáni Magyarországon. in ed., Karády Viktor, Kende Péter, Kovács András, et al, 37-180 (Párizs, Magyar Füzetek, 1985), Karády Viktor, Túlélők és újrakezdők (Budapest: Múlt és Jövő, 2002).

334 Pierre Lagrou, "Return to a Vanished World. European Societies and the Remnants of their Jewish Communities," in The Jews Are Coming Back. The Return of the Jews to Their Countries of Origin after WWII, ed., David Bankier, 1-25 (Jerusalem: Yad Vashem, 2005). Between 1946 and 1960 in Poland, 16,819 Nazi war criminals and Polish collaborators were sentenced. There 
the dead, aided the survivors, but not because they were Jewish, but because this way they could claim to be anti-fascists. Anti-fascism provided an appropriate and comfortable enough framework of memory within which the war became discussable. For the surviving Jews it was an especially suitable framework of assimilation. ${ }^{335}$

The post-war reconstruction of the country entailed the redefinition of the concept of citizenship. The question was who should benefit from the newly launched welfare services. In Eastern Europe the Communists were against the return of Jewish wealth - this is why the heirs of the Csengery Street apartment building lost their right to their inheritance. The argument was that the return of Jewish wealth could spark anti-Semitism. However, anti-Semitism did not need a spark for it to flare up. The concept of "Jewish revenge" was already present at the time of the people's tribunals' trials - and even before. ${ }^{336}$

A former investigator of the Ministry of Internal Affairs told me in an interview what had been on his mind when he was liberated as an 18 year old boy in an Austrian labor camp:

"I had two great resolutions. I was not religious. I took two vows. I went through such horrid events that I would never leave my mother again. Two: I will devote my life to what happened to us, the Jewry." ${ }^{337}$

It was hard to move beyond the "us and them" framework. During the trial Lichter described the Szamocseta-Strucky family as "the maffia of Aryan Hungarians"338 In her testimony Mrs. Szamocseta said the following: "I did not know that internment camps existed, I learned about them only when Christians got interned." 339 These statements clearly mark the clear dividing line between the

were 1,214 death penalty verdicts. See Leszek Kubicki, Zbrodnie wojenne w swietle prawa polskiego (Warszawa: PWN, 1963), 40-41, 180-183. I am grateful for Krzysztof Persak’s help.

335 On the role of Hungarian Jewish organizations, see Kinga Frojimovics, "Different Interprerations of Reconstructions. The AJDC and the WJC in Hungary after the Holocaust," in The Jews Are Coming Back. The Return of the Jews to Their Countries of Origin after WWII, ed., David Bankier, 277-293 (Jerusalem: Yad Vashem, 2005).

336 Karsai László, “'Shylock is Whetting his Blade.' Fear of the Jews’ Revenge in Hungary during World War II," in The Jews Are Coming Back. The Return of the Jews to Their Countries of Origin after WWII, ed., David Bankier, 293-312 (Jerusalem: Yad Vashem, 2005). On revenge, see Andrea Peto", "Digitalized Memories of the Holocaust in Hungary in the Visual History Archive," in Holocaust in Hungary 70 years after, ed., Randolph Braham and András Kovács 253-261 (Budapest: CEU Press, 2016).

337 Interview with Iván Svéd, August 6, 2007.

338 BFL 19273/1949. 265. Lichter's court testimony.

339 BFL 19273/1949. 261. 
two worlds: when Jews were taken away this process remained allegedly unnoticed by the gentiles. This exclusion of course had an impact on Jewish-Hungarian relations. As the psychologist István Kulcsár (1901-1986) characterized the post-war mood of Hungarian Jewry: "Untreated memories, unacknowledged losses, infertile ressentiment, collective residual neurosis, further self-deception, intellectual civil war, see, this is the psychic cross-cut of the remaining Jewry at the fall of 1946." 340

For his part, Lichter did everything to "treat" memories and for that he used the only forum of judicial remedy: the People's Tribunal.

340 Kulcsár István, “A maradék zsidóság lelki keresztmetszete 1946-ban,” Thalassa 1-2 (1994): 336. 